\title{
Aurora B kinase and passenger proteins as targets for cancer therapy
}

Hoang T.M.N., Delacour-Larose M., Molla A.

Department of Cytology, Histology, Embryology and Biophysics, Faculty of Biology, Hanoï University of Sciences, 334 Nguyen Trai road, Hanoï, Viet Nam; Laboratoire de Glaciology et de Géophysique de l'Environnement, UMR CNRS/UJF 5183, 38042 Saint Martin d'Hères, Cedex, France; INSERM U823, UJF, Institut Albert Bonniot, 38706 La Tronche Cedex, France

Abstract: The chromosome passenger complex (CPC) is composed of five proteins: Aurora B kinase, Borealin, INCENP, Survivin and TD-60. CPC functions as an oligo-enzyme, each member activating the catalytic subunit, Aurora B kinase. CPC controls chromosome congression, bidirectional tension on kinetochores and spindle checkpoint signalling as well as cytokinesis completion. CPC is thus a key regulator during mitosis; CPC proteins are exclusively expressed during mitosis and are up-regulated in many tumours. Their overexpression correlates with the level of genomic instability within tumours. Altogether, this leads to the proposal of passenger proteins as potential targets for cancer therapy. This review describes the chromosomal passenger complex and its involvement in mitosis and the different strategies developed towards its inactivation. (C) 2008 Bentham Science Publishers Ltd.

Author Keywords: Aurora kinase; Borealin; Cancer therapy; Chromosome passenger complex; INCENP; Kinase inhibitors; Mitosis; Passenger proteins; Survivin

Index Keywords: 2 aminothiazole derivative; 2,4 dimethyl 5 (2 oxo $1 \mathrm{~h}$ indol 3 ylmethylene) 3 pyrrolepropionic acid; aminopyrazole derivative; aurora B kinase; aurora kinase inhibitor; azd 1152; borealin protein; cet 129202; chromosomal passenger protein; chromosome protein; cyclopropanecarboxylic acid [4 [4 (4 methyl 1 piperazinyl) 6 (5 methyl $2 \mathrm{~h}$ pyrazol 3 ylamino) 2 pyrimidinylthio]phenyl]amide; hesperadin; histone H3; imidazopyridine derivative; inner centromere protein; jnj 7706621; n [4 [6 methoxy 7 (3 morpholinopropoxy) 4 quinazolinylamino]phenyl]benzamide; nuclear protein; pha 680632; pha 739358; protein p53; pyrazoloquinazoline derivative; pyrrolopyrazole derivative; survivin; telophase disc 60 protein; triazolediamine derivative; unclassified drug; carcinogenesis; clinical trial; cytokinesis; down regulation; drug efficacy; drug targeting; endometrium carcinoma; enzyme activation; enzyme activity; enzyme inhibition; enzyme phosphorylation; gene overexpression; genomic instability; human; leukemia; malignant neoplastic disease; melanoma; mitosis; nasopharynx carcinoma; protein expression; protein function; protein localization; review; tumor regression; upregulation

Year: 2008

Source title: Current Enzyme Inhibition

Volume: 4

Issue: 3

Page : 153-159

Cited by: 1

Link: Scorpus Link

Chemicals/CAS: 2,4 dimethyl 5 (2 oxo $1 \mathrm{~h}$ indol 3 ylmethylene) 3 pyrrolepropionic acid, 252916-29-3; 
cyclopropanecarboxylic acid [4 [4 (4 methyl 1 piperazinyl) 6 (5 methyl 2h pyrazol 3 ylamino) 2 pyrimidinylthio]phenyl]amide, 639089-54-6; survivin, 195263-98-0

Tradenames: azd 1152; cct 129202; jnj 7706621; mk 0457; pha 680632; pha 739358; su 6668; vx 680; zm 447439

Correspondence Address: Molla, A.; INSERM U823, UJF, Institut Albert Bonniot, 38706 La Tronche, Cedex, France; email: annie.molla@ujf-grenoble.fr

ISSN: 15734080

DOI: $10.2174 / 157340808785909402$

Language of Original Document: English

Abbreviated Source Title: Current Enzyme Inhibition

Document Type: Review

Source: Scopus

Authors with affiliations:

- Hoang, T.M.N., Department of Cytology, Histology, Embryology and Biophysics, Faculty of Biology, Hanoï University of Sciences, 334 Nguyen Trai road, Hanoï, Viet Nam

- Delacour-Larose, M., Laboratoire de Glaciology et de Géophysique de l'Environnement, UMR CNRS/UJF 5183, 38042 Saint Martin d'Hères, Cedex, France

- Molla, A., INSERM U823, UJF, Institut Albert Bonniot, 38706 La Tronche Cedex, France

References:

- Cooke, C.A., Heck, M.M., Earnshaw, W.C., The inner centromere protein (INCENP) antigens: Movement from inner centromere to midbody during mitosis (1987) J. Cell Biol, 105, pp. 2053-2067

- Bischoff, J.R., Anderson, L., Zhu, Y., Mossie, K., Ng, L., Souza, B., Schryver, B., Plowman, G.D., A homologue of Drosophila aurora kinase is oncogenic and amplified in human colorectal cancers (1998) EMBO J, 17, pp. 3052-3065

- Ambrosini, G., Adida, C., Altieri, D.C., A novel anti-apoptosis gene, survivin, expressed in cancer and lymphoma (1997) Nat. Med, 3, pp. 917-921

- Gassmann, R., Kline, S.L., Carvalho, A., Desai, A., Analysis of kinetochore assembly and function in Caenorhabditis elegans embryos and human cells (2007) Methods, 41, pp. 177-189

- Andreassen, P.R., Palmer, D.K., Wener, M.H., Margolis, R.L., Chromosomal passengers: The four-dimensional regulation of mitotic events (1991) J. Cell Sci, 99 (PART 3), pp. 523-534

- Martineau-Thuillier, S., Andreassen, P.R., Margolis, R.L., Colocalization of TD-60 and INCENP throughout G2 and mitosis: Evidence for their possible interaction in signalling cytokinesis (1998) Chromosoma, 107, pp. 461-470

- Ruchaud, S., Carmena, M., Earnshaw, W.C., Chromosomal passengers: Conducting cell division (2007) Nat. Rev. Mol. Cell Biol, 8, pp. 798-812

- Vagnarelli, P., Earnshaw, W.C., Chromosomal passengers: The four-dimensional regulation of mitotic events (2004) Chromosoma, 113, pp. 211-222

- Bolton, M.A.

- Lan, W.

- Powers, S.E

- McCleland, M.L.

- Kuang, J.

- Stukenberg, P.T. Aurora B kinase exists in a complex with survivin and INCENP and its kinase activity is stimulated by 
survivin binding and phosphorylation. Mol. Biol. Cell, 2002, 13, 3064-77Sessa, F., Mapelli, M., Ciferri, C., Tarricone, C., Areces, L.B., Schneider, T.R., Stukenberg, P.T., Musacchio, A., Mechanism of Aurora B activation by INCENP and inhibition by hesperadin (2005) Mol. Cell, 18, pp. 379-391

- Jelluma, N., Brenkman, A.B., van den Broek, N.J., Cruijsen, C.W., van Osch, M.H., Lens, S.M., Medema, R.H., Kops, G.J., Mps1 phosphorylates Borealin to control Aurora B activity and chromosome alignment (2008) Cell, 132, pp. 233-246

- Mollinari, C., Reynaud, C., Martineau-Thuillier, S., Monier, S., Kieffer, S., Garin, J., Andreassen, P.R., Margolis, R.L., The mammalian passenger protein TD-60 is an RCC1 family member with an essential role in prometaphase progression (2003) Dev. Cell, 5, pp. 295-307

- Rosasco-Nitcher, S.E., Lan, W., Khorasanizadeh, S., Stukenberg, P.T., Centromeric Aurora-B activation requires TD-60, microtubules, and substrate priming phosphorylation (2008) Science, 319, pp. 469-472

- Jeyaprakash, A.A., Klein, U.R., Lindner, D., Ebert, J., Nigg, E.A., Conti, E., Structure of Survivin-Borealin-INCENP Core Complex Reveals How Chromosomal Passengers Travel Together (2007) Cell, 131, pp. 271-285

- Delacour-Larose, M., Molla, A., Skoufias, D.A., Margolis, R.L., Dimilrov, S., Distinct Dynamics of Aumra B and Survivin during Mitosis (2004) Cell Cycle, 3, pp. 1418-1426

- Delacour-Larose, M., Thi, M.N., Dimitrov, S., Molla, A., Role of Survivin Phosphorylation by Aurora B in Mitosis (2007) Cell Cycle, 6, pp. 1878-1885

- Han, Z., Riefler, G.M., Saam, J.R., Mango, S.E., Schumacher, J.M., The C. elegans Tousled-like kinase contributes to chromosome segregation as a substrate and regulator of the Aurora B kinase (2005) Curr. Biol, 15, pp. 894-904

- Zachos, G., Black, E.J., Walker, M., Scott, M.T., Vagnarelli, P., Earnshaw, W.C., Gillespie, D.A., Chk1 is required for spindle checkpoint function (2007) Dev. Cell, 12, pp. 247-260

- Adams, R.R., Maiato, H., Earnshaw, W.C., Carmena, M., Essential Roles of Drosohila Inner Centromere Protein [INCENP] and Aurora B in Histone H3 Phosphorylation, Metaphase Chromosome Alignmeny, Kinetochore Disjunction, and Chromosome Segregation (2001) J. Cell Biol, 153, pp. 865-880

- Gassmann, R.

- Carvalho, A.

- Henzing, A.J.

- Ruchaud, S.

- Hudson, D.F.

- Honda, R.

- Nigg, E.A.

- Gerloff, D.L.

- Earnshaw, W.C. Borealin: a novel cbromosomal passenger required for stability of the mitotic spindle. J. Cell Biol., 2004, 166, 179-91Brito, D.A., Rieder, C.L., Mitotic checkpoint slippage in humans occurs via cyclin B destruction in the presence of an active checkpoint (2006) Curr. Biol, 16, pp. 1194-1200

- Hontz, A.E., Li, S.A., Lingle, W.L., Negron, V., Bruzek, A., Salisbury, J.L., Li, J.J., Aurora a and B overexpression and centrosome amplification in early estrogen-induced tumor foci in the Syrian hamster kidney: Implications for chromosomal instability, aneuploidy, and neoplasia (2007) Cancer Res, 67, pp. 2957-2963

- Sorrentino, R.

- Libertini, Pallante, P.L.

- Troncone, G.

- Palombini, L. 
- Bavetsias, V.

- Spalletti-Cernia, D.

- Laccetti, P.

- Linardopoulos, S.

- Chieffi, P.

- Fusco, A.

- Portella, G. Aurora B overexpression associates with the thyroid carcinoma undifferentiated phenotype and is required for thyroid carcinoma cell proliferation. J. Clin. Endocrinol. Metab., 2005, 90, 928-35Giet, R., Petretti, C., Prigent, C., Aurora kinases, aneuploidy and cancer, a coicidence or a real link? (2005) Trends Cell Biol, 15, pp. 241-250

- Ota, T., Suto, S., Katayama, H., Han, Z.B., Suzuki, F., Maeda, M., Tanino, M., Tatsuka, M., Increased mitotic phosphorylation of histone $\mathrm{H} 3$ attributable to AIM-1/Aurora-B overexpression contributes to chromosome number instability (2002) Cancer Res, 62, pp. 5168-5177

- Sun, C., Chan, F., Briassouli, P., Linardopoulos, S., Aurora kinase inhibition downregulates NF-kappaB and sensitises tumour cells to chemotherapeutic agents (2007) Biochem. Biophys. Res. Commun, 352, pp. 220-225

- Kanda A.

- Kawai H.

- Suto S.

- Kitajima S.

- Sato S.: Takata T.

- Tatsuka M. Aurora-B/AIM-1 kinase activity is involved in Rasmediated cell transformation. Oncogene, 2005, 49, 7266-72Li, F., Ling, X., Survivin study: An update of "what is the next wave"? (2006) J. Cell Physiol, 208, pp. 476-486

- Altieri, D.C., Survivin and apoptosis control (2003) Adv. Cancer Res, 88, pp. 31-52

- Fukuda, S., Pelus, L.M., Survivin, a cancer target with an emerging role in normal adult tissues (2006) Mol. Cancer Ther, 5, pp. 1087-1098

- Caldas, H., Jiang, Y., Holloway, M.P., Fangusaro, J., Mahotka, C., Conway, E.M., Altura, R.A., Survivin splice variants regulate the balance between proliferation and cell death (2005) Oncogene, 24, pp. 1994-2007

- Yu, J., Leung, W.K., Ebert, M.P., Ng, E.K., Go, M.Y., Wang, H.B., Chung, S.C., Sung, J.J., Increased expression of survivin in gastric cancer patients and in first degree relatives (2002) Br. J. Cancer, 87, pp. 91-97

- Xia, F., Canovas, P.M., Guadagno, T.M., Altieri, D.C., A survivin-Ran complex regulates spindle formation in tumor cells (2008) Mol. Cell Biol, , in press

- Chang, J.L., Chen, T.H., Wang, C.F., Chiang, Y.H., Huang, Y.L., Wong, F.H., Chou, C.K., Chen, C.M., Borealin/Dasra B is a cell cycle-regulated chromosomal passenger protein and its nuclear accumulation is linked to poor prognosis for human gastric cancer (2006) Exp. Cell Res, 312, pp. 962-973

- Adams, R.R., Eckley, D.M., Vagnarelli, P., Wheatley, S.P., Gerloff, D.L., Mackay, A.M., Svingen, P.A., Earnshaw, W.C., Human INCENP colocalizes with the Aurora-B/AIRK2 kinase on chromosomes and is overexpressed in tumour cells (2001) Chromosoma, 110, pp. 65-74

- Date, D.A., Jacob, C.J., Bekier, M.E., Stiff, A.C., Jackson, M.W., Taylor, W.R., Borealin is repressed in response to p53/Rb signaling (2007) Cell Biol. Int, 12, pp. 470-481

- Hayama, S., Daigo, Y., Yamabuki, T., Hirata, D., Kato, T., Miyamoto, M., Ito, T., Nakamura, Y., Activation of CDCA1KNTC2, members of centromere protein complex, involved in pulmonary carcinogenesis (2007) Cancer Res, 67, pp. 4113-4122

- Chen, J.S., Liu, J.C., Shen, L., Rau, K.M., Kuo, H.P., Li, Y.M., Shi, D., Hung, M.C., Cancer-specific activation of the survivin 
promoter and its potential use in gene therapy (2004) Cancer Gene Ther, 11, pp. 740-747

- Fischer, U., Schulze-Osthoff, K., New approaches and therapeutics targeting apoptosis in disease (2005) Pharmacol. Rev, 57, pp. $187-215$

- Nakahara, T., Takeuchi, M., Kinoyama, I., Minematsu, T., Shirasuna, K., Matsuhisa, A., Kita, A., Sasamata, M., YM155, a novel small-molecule survivin suppressant, induces regression of established human hormone-refractory prostate tumor xenografts (2007) Cancer Res, 67, pp. 8014-8021

- Yan, H., Thomas, J., Liu, T., Raj, D., London, N., Tandeski, T., Leachman, S.A., Grossman, D., Induction of melanoma cell apoptosis and inhibition of tumor growth using a cell-permeable Survivin antagonist (2006) Oncogene, 25, pp. 6968-6974

- Harrington, E.A., Bebbington, D., Moore, J., Rasmussen, R.K., Ajose-Adeogun, A.O., Nakayama, T., Graham, J.A., Miller, K.M., VX-680, a potenr and selective small-mplecule inhibitor of the Aurora kinases, suppresses tumor growth in vivo (2004) Nat. Med, 10, pp. 262-267

- Gautschi, O., Heighway, J., Mack, P.C., Purnell, P.R., Lara Jr., P.N., Gandara, D.R., Aurora kinases as anticancer drug targets (2008) Clin. Cancer Res, 14, pp. 1639-1648

- Giles, F.J., Cortes, J., Jones, D., Bergstrom, D., Kantarjian, H., Freedman, S.J., MK-0457, a novel kinase inhibitor, is active in patients with chronic myeloid leukemia or acute lymphocytic leukemia with the T3151 BCR-ABL mutation (2007) Blood, 109, pp. 500-502

- Girdler, F., Sessa, F., Patercoli, S., Villa, F., Musacchio, A., Taylor, S., Molecular basis of drug resistance in aurora kinases (2008) Chem. Biol, 6, pp. 552-562

- Li, Y., Kao, G.D., Garcia, B.A., Shabanowitz, J., Hunt, D.F., Qin, J., Phelan, C., Lazar, M.A., A novel histone deacetylase pathway regulates mitosis by modulating Aurora B kinase activity (2006) Genes Dev, 20, pp. 2566-2579

- Wilkinson, R.W.

- Odedra, R.

- Heaton, S.P.

- Wedge, S.R

- Keen, N.J.

- Crafter, C.

- Foster, J.R.

- Brady, M.C.

- Bigley, A.

- Brown, E.

- Byth, K.F.

- Barrass, N.C.

- Mundt, K.E.

- Foote, K.M.

- Heron, N.M.

- Jung, F.H.

- Mortlock, A.A.

- Boylé, F.T.

- Green, S. AZD1152, a selective inhibitor of Aurora B kinase, inhibits human tumor xenograft growth by inducing apoptosis. Clin. Cancer Res., 2007, 13, 3682-8Kim, K.W., Mutter, R.W., Wiley, C.D., Subhawong, T.K., Shinohara, E.T., Albert, J.M., Ling, G., Lu, B., Inhibition of survivin and aurora B kinase sensitizes mesothelioma cells by enhancing mitotic arrests (2007) 
Int. J. Radiat. Oncol. Biol. Phys, 67, pp. 1519-1525

- Girdler, F., Gascoigne, K.E., Eyers, P.A., Hartmuth, S., Crafter, C., Foote, K.M., Keen, N.J., Taylor, S.S., Validating Aurora B as an anti-cancer drug target (2006) J. Cell Sci, 119, pp. 3664-3675

- Hauf, S., Cole, R.W., LaTerra, S., Zimmer, C., Schnapp, G., Walter, R., Heckel, A., Peters, J.M., The small molecule Hesperadin reveals a role for Aurora B in correcting kinetochore-microtubule attachment and in maintaining the spindle assembly checkpoint (2003) J. Cell Biol, 161, pp. 281-294

- Ditchfield, C., Johnson, V.L., Tighe, A., Ellston, R., Haworth, C., Johnson, T., Mortlock, A., Taylor, S.S., Aurora B couples chromosome augment with anaphase by targeting BubR1, Mad2, and Cenp-E to kinotochore (2003) J. Cell Biol, 161, pp. 267280

- Godl, K., Gruss, O.J., Eickhoff, J., Wissing, J., Blencke, S., Weber, M., Degen, H., Daub, H., Proteomic characterization of the angiogenesis inhibitor SU6668 reveals multiple impacts on cellular kinase signaling (2005) Cancer Res, 65, pp. 6919-6926

- Emanuel, S., Rugg, C.A., Gruninger, R.H., Lin, R., Fuentes-Pesquera, A., Connolly, P.J., Wetter, S.K., Middleton, S.A., The in vitro and in vivo effects of JNJ-7706621: A dual inhibitor of cyclin-dependent kinases and aurora kinases (2005) Cancer Res, 65, pp. 9038-9046

- Soncini, Carpinelli, P.

- Gianellini, L.

- Fancelii, D.

- Vianello, P.

- Rusconi, L.

- Storici, P.

- Zugnoni, P.

- Pesenti, E.

- Croci, V.

- Ceruti, R.

- Giorgini, M.L.

- Cappella, P.

- Ballinari, D.

- Sola, F.

- Varasi, M.

- Bravo, R.

- Moll, J. PHA-680632, a Novel Aurora Kinase Inhibitors with Potent Antitumoral Activity. Clin. Cancer Res. 2006, 12, 40809Carpinelli, P., Ceruti, R., Giorgini, M.L., Cappella, P., Gianellini, L., Croci, V., Degrassi, A., Moll, J., PHA-739358, a potent inhibitor of Aurora kinases with a selective target inhibition profile relevant to cancer (2007) Mol. Cancer Ther, 6, pp. 31583168

- Chan, F., Sun, C., Perumal, M., Nguyen, Q.D., Bavetsias, V., McDonald, E., Martins, V., Linar-dopoulos, S., Methanism of action of the Aurora kinase inhibitor CCT129202 and in vivo quantification of biological activity (2007) Mol. Cancer Ther, 6, pp. $3147-3157$

- Jung, F.H., Pasquet, G., Lambert-van der Brewpt, C., Lohmann, J.J., Warin, N., Renaud, F., Germain, H., Brightwell, S., Discovery of novel and potent thiazoloquinazolines as selective Aurora A and B kinase inhibitors (2006) J. Med. Chem, 49, pp. 955-970 